\title{
Effect of Ascorbic, Folic acids and Hibiscus Extract on Geranium (Pelargonium graveolens)
}

\author{
Tamer Farouk Ahmed El-Moghazy ${ }^{*}$, Esam Abd-Elkareem Abd-Elazeem Al-Azzony \\ Medicinal and Aromatic Plants Research Department, Horticulture Research Institute, Agriculture Research Center, Giza, Egypt \\ Email address: \\ drtamerelmo051@gmail.com (T. F.A. El-Moghazy), esam.karm221@gmail.com (E. A. A. Al-Azzony) \\ ${ }^{*}$ Corresponding author \\ To cite this article: \\ Tamer Farouk Ahmed El-Moghazy, Esam Abd-Elkareem Abd-Elazeem Al-Azzony. Effect of Ascorbic, Folic acids and Hibiscus Extract on \\ Geranium (Pelargonium graveolens). American Journal of Plant Biology. Vol. 4, No. 4, 2019, pp. 46-56. doi: 10.11648/j.ajpb.20190404.11
}

Received: September 12, 2019; Accepted: September 29, 2019; Published: October 12, 2019

\begin{abstract}
The present investigation was carried out in Sabahia Horticulture Research Station, Alexandria, Egypt during 2015/2016 - 2016/2017 seasons to study the effect of foliar application with ascorbic acid, folic acid as well as hibiscus extract on quality of Geranium (Pelargonium graveolens L.). Foliar application of ascorbic acid and folic acid as well as extract of hibiscus were sprayed twice in each cut (first spry before cut 60 days and second spray before cut 30 days). Treatments included: control "water only", ascorbic acid at (100 and $200 \mathrm{ppm})$, folic acid at (50 and 100ppm) and hibiscus extract at (5\% and $10 \%)$. The essential oil (\%) of Geranium was determined by hydro-distillation as well as the main constituents of the volatile oil were determined by (GC). The Results showed that, all treatments (tested) caused a great increase in vegetative growth, the essential oil (\%), oil yield (ml/plant and L/Fed.) and active compounds; Citronerlol, Citronelly formate, Isomenthone, B-caryophyllene and Geranyl formate, while it decreased $\alpha$-pinene and Geraniol. In addition, ascorbic acid at $200 \mathrm{ppm}$, folic acid at $100 \mathrm{ppm}$ and hibiscus extract at $(5,10 \%)$ are sharp efficacy on increasing the vegetative growth and volatile oil yield than other treatments. Furthermore, it could be illustrated that natural drying caused pronounced changes (acceptable) in the volatile oil\% and main constituents.
\end{abstract}

Keywords: Geranium, Essential Oil, Ascorbic Acid, Folic Acid, Hibiscus Extract, Natural Drying

\section{Introduction}

Pelargonium graveolens L. (Geranium, family; Geraniaceae). Major areas of the production (about 5795 fed.) are primarily in mainly Bani Sweif (4057 fed.) followed by Giza (1500 fed.) and Minya (110 fed.) Governorates. Two harvests (cuts) are taken per year; a spring cut from April to June and a summer cut from September to October. Generally, the production averaged by 105581 ton in 2016 year [1]. The volatile oil of Geranium is widely used in the perfumery and cosmetic industries [2-4]. It is an indispensable aromatherapy oil since geranium oil and its major constituents citronellol, geraniol, and linalool [5]. Geranium volatile oil has also become important skin care oil because it is good in opening skin pores and cleaning oily complexions $[6,7]$. This oil has also been found to have use in reducing pain due to postherpetic neuralgia, treating dysentery, hemorrhoids, inflammation, heavy menstrual flows, and cancer [6]. The French community is currently treating diabetes as well as diarrhea, gallbladder problems, gastric ulcers, jaundice, liver problems, sterility, and urinary stones with this oil [6, 8, 9]. Moreover furthermore, in Chinese homeopathy, it is thought to open up the liver chakra and promote the expulsion of toxins, helping to achieve a balanced body [10]. Also Geranium essential oil exhibited efficacy on keep the treated peach fruits during cold storage and market life periods [11].

Many biochemical effects of vitamins, one that has factor more recent attention is the improvement of yield and quality of many plants. And especially, enhancing growth and productivity will be of more importance to increase the yield [12-15]. Vitamin Ascorbic acid (C) has a regulatory role in promoting productivity in many plants such as pepper [16]. Balbaa and Talaat (2007) who concluded that with ascorbic acid, phenylalanine and ornithine treatments significantly increased plant height $(\mathrm{cm})$ and number of branches/plant of Rosmary plants [17]. Thymus treated with phenylalanine, 
tryptophan or ascorbic acid at different concentrations caused a significantly increment of plant height $(\mathrm{cm})$ and number of branches/plant compared with untreated plants [18]. However, Ascorbic acid (vitamin C) is one Important from vitamins, it is play important roles in plant growth, cell division, cell wall ex-pansion, and other developmental processes [19-21]. And also is synthesized in the higher plants and affects growth of plant and development, it is Dglucose metabolism product which affects some nutritional cycles activity in higher plants and play an important role in the electron transport system [22]. On the other hand, folic acid (vit. B9) has become the most prominent of B complex vitamins despite its essential biochemical function in amino acids metabolism and nucleic acids synthesis [23]. Folic acid (vit. B9) was first isolated from Spinacia oleracea L. (1941) and characterized as pteroylmonoglutamic acid, a complex water soluble vitamin B [24, 25]. Foliar treatment of strawberry plants with both concentrations of folic acid, significantly improved agronomic properties of the treated plants including yield, primary and secondary weight of fruits and number of their achenes as compared to the control treatment [26].

Rosella "Karkadeh in Arabic", (Hibiscus sabdariffa L., family; Malvaceae), and is mainly cultivated in tropical and subtropical regions of Asia and Africa. The water extract from the calyx is consumed as hot and cold drink. It is also used in the production of Karkadeh jam and as a food colouring agent [27]. Major areas of the production in Egypt (about 12232 fed.) are primarily in mainly Luxor (6058fed.) followed by Aswan (5861 fed.). Generally, the production averaged by 12809 ton in 2016 year [1]. The in vivo pharmacological activities as antipyretic, antioxidant as well as anticholesterol products were screened in rats and rabbits [28]. It was also proved effective in regulating human blood pressure [29, 30].

Hibiscus extract: The physico-chemical analysis of water extract of Roselle calyces, the calcium content was $0.55 \mathrm{mg} / \mathrm{g}$, potassium content was $0.46 \mathrm{mg} / \mathrm{g}$, sodium $0.33 \mathrm{mg} / \mathrm{g}$, iron $0.22 \mathrm{mg} / \mathrm{g}$, magnesium $0.21 \mathrm{mg} / \mathrm{g}$, manganese $0.001 \mathrm{mg} / \mathrm{g}$ and copper content was $0.03 \mathrm{mg} / \mathrm{g}$. Every enzyme needs cofactors to function properly; most of these factors are mineral elements. These results reinforce its uses as a nutrition source for human. The ph of the water extract was found to be 2.35 this indicated that the karkade extract has a reasonable taste for drinking. The moisture content was $10.8 \mathrm{~g} / 100 \mathrm{~g}$ and the ash was $9.7 \mathrm{~g} / 100 \mathrm{~g}$. [31]. Chemical composition of Roselle: ash $8-12 \%$, protein $5-10 \%$, carbohydrate $60-62 \%$, vitamin C $92.0 \mathrm{mg} / 100 \mathrm{~g}$, organic acids (hibiscic acid $25.5 \%$, citric acid $14.15 \%$, vitamin C $92.7 \mathrm{mg} / 100 \mathrm{~g}$, oxalic acid $0.6 \%$ ), mineral contents (Ca $0.56 \%$, mg $0.24 \%$, fe $0.08 \%$, na $0.23 \%$, $\mathrm{k}$ $0.95 \%$, p $0.19 \%$ ) and total anthocyanin 0.9 to $1.6 \%$ [32]. Flavonoid compounds of hibiscus flower extract (caffeic acid 4.5, Gallic acid 0.9, Homogentisic acid 3.2, pyrogallol 1031.7, 3,4-Dihydroxybenzoic acid 0.7 and 2,5Dihydroxybenzoic acid $6.7 \mathrm{mg} / 100 \mathrm{ml}$ [33].

The main target of the present study was to improve the growth and productivity of Germanium by some vitamins and Hibiscus extract and evaluate the effect of natural drying on the content and chemical composition of the essential oil.

\section{Materials and Methods}

\subsection{Plant Material}

The research was carried out at the Sabahiya, Horticulture Research Station in, Alexandria, Egypt during two successive seasons of 2015/2016 and 2016/2017, to study the effect of ascorbic, folic acid and hibiscus extract on quality of Geranium (oil\%, active compounds and vegetative growth). Seedlings were planted at the end (April/2015) in pots. Foliar application of ascorbic acid and folic acid as well as extract of hibiscus were sprayed twice in each cut (first spry before cut 60 days and second spray before cut 30 days) and taken two cut in each season.

\subsection{Preparation of the Hibiscus Extract}

Collect the fresh hibiscus (Roselle) calyx and natural drying at room temperature until constant weight. The dry calyx was powder using automatic blender and taken $50 \mathrm{~g}$ and $100 \mathrm{~g}$ of dried calyx was placed in $1000 \mathrm{~mL}$ water under stirring and then left for 12 hours then filtration and used to spray plants.

\subsection{The Treatments Were as Follows}

1. Treat. (T1) sprayed with water Control.

2. Treat. (T2) sprayed with ascorbic acid at concentration at $100 \mathrm{ppm}$.

3. Treat. (T3) sprayed with ascorbic acid at concentration at $200 \mathrm{ppm}$.

4. Treat. (T4) sprayed with folic acid at concentration at $50 \mathrm{ppm}$.

5. Treat. (T5) sprayed with folic acid at concentration at $100 \mathrm{ppm}$.

6. Treat. (T6) sprayed with extract of hibiscus at concentration at $5.0 \%$.

7. Treat. (T7) sprayed with extract of hibiscus at concentration at $10.0 \%$.

\subsection{Harvest}

The plants were harvested first cut (October) and second cut (May) in both seasons.

\subsection{Data Were Recorded}

\subsubsection{Vegetative Growth}

i. Plant height $(\mathrm{cm})$

a. Number of branches (N/plant)

b. Fresh and dry weights (g/plant)

\subsubsection{The Fresh and Dry Herbs Yield (Ton/Fed.)}

$\frac{\text { Fresh or dry weight (g/plant) } x \text { number plants } / \text { fed.(30000) }}{1000000}$ 


\subsubsection{The Essential Oil Percentage (\%)}

A hundred (g) fresh (after $24 \mathrm{~h}$. from cut) and dry Geranium herb (after 2 weeks from natural drying at room temperature $20 \pm 2^{\circ} \mathrm{C}$ until constant weight) were subjected to three-hours of hydro-distillation using a Clevenger-type apparatus as described by [34].

\subsubsection{The Essential Oil Yield (ml/plant)}

$\frac{\text { Essential oil } \% x \text { Fresh or dry plant weight (g/plant) }}{100}$

\subsubsection{The Essential Oil Yield (L/Fed.)}

Oil yield (ml/plant) $x$ number plants/fed.(30000)

$$
1000
$$

\subsubsection{Chemical Composition (Active Compounds) of Essential Oil}

The GC analysis of volatile oil samples was carried out using gas chromatography instrument stands at the Medicinal and Aromatic Plants Res. Dept., Hort. Res. Inst. With the following specifications. DsChrom 6200Gas Chromatograph equipped with a flame ionization detector, Column: BPX-5, $5 \%$ Phenyl (equiv.) polysillphenylene-siloxane $30 \mathrm{~m} \mathrm{x}$ $0.25 \mathrm{~mm}$ ID x $0.25 \mu \mathrm{m}$ film., Sample size: $1 \mu \mathrm{l}$, Temperature program ramp increase with a rate of $10^{\circ} \mathrm{C} / \mathrm{min}$ from $70^{\circ} \mathrm{C}$ to $200^{\circ} \mathrm{C}$, Detector temperature (FID): $280^{\circ} \mathrm{C}$, Carrier gas: nitrogen, Flow rate: N2 30ml/min; H2 $30 \mathrm{ml} / \mathrm{min}$; air $300 \mathrm{ml} / \mathrm{min}$. Main compounds of the volatile oils were identified by matching their retention times with those of the authentic samples injected under the same conditions. The relative percentage of each compound was calculated from the area of the peak corresponding to each compound.

\subsection{Experimental Design and Statistical Analysis}

Data of the present study were subjected to the analysis of variance test (ANOVA) as Randomized Complete Block Design. Where the first factor was for seven treatments mentioned before, the second factor was for cuts. The least significant differences (LSD at the $5 \%$ ) of probability were calculated by a computer program (Costat, version 6.303, 2005) according to the study [35].

\section{Results and Discussion}

\subsection{Vegetative Growth}

\subsubsection{Plant Height (cm) and Number of Branches (N/plant)}

Data of studying the effect of ascorbic acid, folic acid and hibiscus extract on plant height $(\mathrm{cm})$ and number of branches/ plant of Geranium during 2015/2016 - 2016/2017 seasons are reported in (Table 1) and (Figure 1) in two seasons of study, results showed that all treatments caused a significantly increase in plant height $(\mathrm{cm})$ and number of branches/ plant compared with control. In addition, ascorbic acid at $200 \mathrm{ppm}$, folic acid 100ppm and hibiscus extract at $5 \%$ and $10 \%$ in both seasons were sharp efficacy on increasing plant height $(\mathrm{cm})$ and number- branches/ plant than other treatments and control.

Regarding the effect of cuts date, statistical analysis show that, plant height $(\mathrm{cm})$ and number of branches/ plant were gradually increase and significantly with the second cut compared with first cut in both seasons.

Table 1. Effect of ascorbic acid, folic acid and hibiscus extract on plant height (cm) and number of branches/ plant of Geranium during $2015 / 2016-$ $2016 / 2017$ seasons.

\begin{tabular}{|c|c|c|c|c|c|c|c|c|c|c|c|c|}
\hline \multirow{3}{*}{ Treatments } & \multicolumn{6}{|c|}{ First season } & \multicolumn{6}{|c|}{ Second season } \\
\hline & \multicolumn{3}{|c|}{ Plant height (cm) } & \multicolumn{3}{|c|}{ Number of branches/plant } & \multicolumn{3}{|c|}{ Plant height (cm) } & \multicolumn{3}{|c|}{ Number of branches/plant } \\
\hline & $\mathbf{1}^{\text {st }} \mathrm{Cut}$ & $2^{\text {nd }}$ Cut & Means & $1^{\text {st }} \mathrm{Cut}$ & $2^{\text {nd }}$ Cut & Means & $1^{\text {st }}$ Cut & $2^{\text {nd }}$ Cut & Means & $1^{\text {st }}$ Cut & $2^{\text {nd }}$ Cut & Means \\
\hline Control & 50.66 & 71.33 & 61 & 6.33 & 11.33 & 8.83 & 54.93 & 63 & 58.96 & 8.66 & 8.66 & 8.66 \\
\hline \multicolumn{13}{|l|}{ Ascorbic acid } \\
\hline $100 \mathrm{ppm}$ & 54.33 & 84.25 & 69.29 & 7.33 & 11.66 & 9.5 & 68.5 & 76.66 & 72.58 & 8.93 & 10 & 9.46 \\
\hline $200 \mathrm{ppm}$ & 59.36 & 86.16 & 72.76 & 8 & 12.66 & 10.33 & 76.33 & 85 & 80.66 & 9.33 & 10.33 & 9.83 \\
\hline \multicolumn{13}{|l|}{ Folic acid } \\
\hline $50 \mathrm{ppm}$ & 53.5 & 79 & 66.25 & 6.88 & 11.66 & 9.27 & 62.66 & 68.33 & 65.5 & 8.66 & 9.33 & 9 \\
\hline $100 \mathrm{ppm}$ & 57.1 & 84 & 70.55 & 7.33 & 12 & 9.66 & 65.33 & 78.33 & 71.83 & 8.8 & 9.66 & 9.26 \\
\hline \multicolumn{13}{|l|}{ Extracted-hibiscus } \\
\hline $5 \%$ & 59.43 & 87.33 & 73.38 & 7.33 & 11.66 & 9.5 & 76.33 & 86.66 & 81.5 & 9.66 & 10 & 9.83 \\
\hline $10 \%$ & 62.06 & 102.76 & 82.37 & 7.66 & 11.66 & 9.66 & 82.66 & 88.33 & 85.5 & 10 & 10.33 & 10.16 \\
\hline Means cuts & 56.63 & 84.96 & & 7.26 & 11.8 & & 69.53 & 78.04 & & 9.16 & 9.76 & \\
\hline L.S.D. Treatments & 3.87 & & & 0.85 & & & 7.32 & & & 0.735 & & \\
\hline Cuts & 2.07 & & & 0.45 & & & 3.914 & & & 0.393 & & \\
\hline Interaction Tre.xcuts & 4.53 & & & 0.991 & & & 8.56 & & & 0.859 & & \\
\hline
\end{tabular}

The interactions among treatments and cuts dates revealed that significantly decreased plant height $(\mathrm{cm})$ and number of branches/ plant in first cut. Ascorbic acid, folic acid and hibiscus extract treatments were more effective on increasing plant height $(\mathrm{cm})$ and number of branches/ plant than first cut in both seasons.

Plant height $(\mathrm{cm})$ 


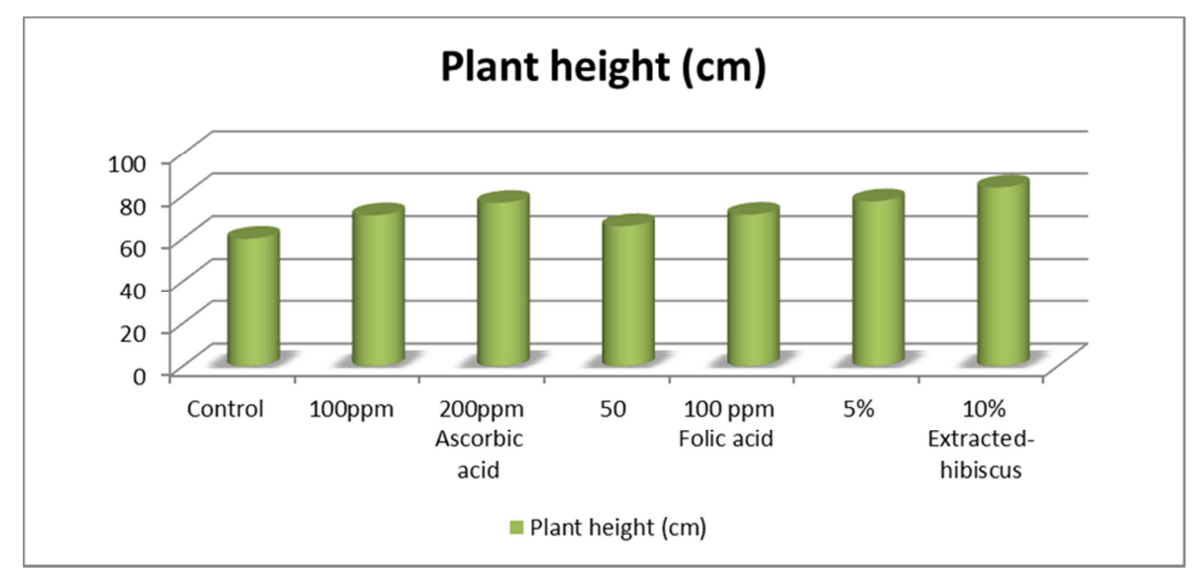

Figure 1. Effect of ascorbic acid, folic acid and hibiscus extract on plant height (cm) of Geranium in both seasons.

Many biochemical effects of vitamins, one that has factor more recent attention is the improvement of yield and quality of many plants. And especially, enhancing growth and productivity will be of a more importance to increase the yield [12-15]. The results obtained showed that foliar application of Geranium plants with ascorbic acid, folic acid, hibiscus extract, significantly increase plant high $(\mathrm{cm})$ and number of branches/ plant the experimental period. Similar results were obtained by Balbaa and Talaat (2007) who found that ascorbic acid treatment significantly increased plant height $(\mathrm{cm})$ and number of branches/plant of Rosmary plants [17]. And also Ghazal (2015) reported that plant (Thymus vulgaris L.) treated with ascorbic acid at different concentrations caused a great increased of plant height $(\mathrm{cm})$ and number of branches/ plant at (100 and 150ppm) compared with control [18]. However, Ascorbic acid (vitamin C) is one Important from vitamins, it is play important roles in plant growth, cell division, cell wall expansion, and other developmental processes [19-21]. On the other hand, folic acid (vitamin B9) has become the most prominent of $\mathrm{B}$ complex vitamins despite its essential biochemical function in amino acids metabolism and nucleic acids synthesis [23]. The present results are in a general harmony with those of Emam et al., (2011) who found that foliar application of flax plants with either folic acid or ascorbic acid significantly stimulated growth and development throughout the experimental [36]. Chemical composition of Roselle: ash $8-12 \%$, protein $5-10 \%$, carbohydrate $60-62 \%$, vitamin C $92.0 \mathrm{mg} / 100 \mathrm{~g}$, organic acids (hibiscic acid $25.5 \%$, citric acid $14.15 \%$, vitamin C 92.7 $\mathrm{mg} / 100 \mathrm{~g}$, oxalic acid $0.6 \%$ ), mineral contents (Ca $0.56 \%$, mg $0.24 \%$, fe $0.08 \%$, na $0.23 \%$, k $0.95 \%$, p $0.19 \%$ ) and total anthocyanin 0.9 to $1.6 \%$ [32]. The effect of hibiscus extract treatment on plant height $(\mathrm{cm})$ and number of branches/plant may be due to its effect on enzyme activity as a (cofactor) and metabolism, as it contains; ascorbic acid, mineral elements and anthocyanin.

\subsubsection{Fresh and Dry Weights (g/plant)}

Data presented in (Table 2) indicated that when foliar application with ascorbic acid, folic acid and hibiscus extract, they significantly increased of fresh and dry weighs ( $\mathrm{g} / \mathrm{plant}$ ) when compared with the control treatment in both seasons. On the other hand ascorbic acid at 200ppm, folic acid $100 \mathrm{ppm}$ and hibiscus extract at $5 \%$ and $10 \%$ in two seasons were more effective on increasing fresh and dry weights ( $g /$ plant) than other treatments.

Table 2. Effect of ascorbic acid, folic acid and hibiscus extract on fresh and dry weights (g./plant) of Geranium during 2015/2016 - 2016/2017 seasons.

\begin{tabular}{|c|c|c|c|c|c|c|c|c|c|c|c|c|}
\hline \multirow{3}{*}{ Treatments } & \multicolumn{6}{|c|}{ First season } & \multicolumn{6}{|c|}{ Second season } \\
\hline & \multicolumn{3}{|c|}{ Fresh weight (g./plant) } & \multicolumn{3}{|c|}{ Dry weight (g./plant) } & \multicolumn{3}{|c|}{ Fresh weight (g./plant) } & \multicolumn{3}{|c|}{ Dry weight (g./plant) } \\
\hline & $1^{\text {st }} \mathrm{Cut}$ & $2^{\text {nd }}$ Cut & Means & $1^{\text {st }} \mathrm{Cut}$ & $2^{\text {nd }} \mathrm{Cut}$ & Means & $1^{\text {st }} \mathrm{Cut}$ & $2^{\text {nd }}$ Cut & Means & $1^{\text {st }}$ Cut & $2^{\text {nd }} \mathrm{Cut}$ & Means \\
\hline Control & 327.66 & 413.33 & 370.5 & 93.66 & 122.43 & 108.05 & 351 & 360 & 355.5 & 104 & 101.66 & 102.83 \\
\hline \multicolumn{13}{|l|}{ Ascorbic acid } \\
\hline $100 \mathrm{ppm}$ & 350 & 433 & 391.5 & 101.1 & 137.46 & 119.28 & 370.33 & 383 & 376.83 & 116.66 & 119.66 & 118.16 \\
\hline $200 \mathrm{ppm}$ & 356.66 & 440.33 & 398.5 & 106.66 & 141.66 & 124.16 & 372 & 386.66 & 379.33 & 125 & 129 & 127 \\
\hline \multicolumn{13}{|l|}{ Folic acid } \\
\hline $50 \mathrm{ppm}$ & 340 & 431.66 & 385.83 & 98.33 & 130.76 & 114.55 & 360.33 & 376.66 & 368.5 & 102.6 & 111.66 & 107.16 \\
\hline $100 \mathrm{ppm}$ & 355 & 435.66 & 395.33 & 101.66 & 136.33 & 119 & 366 & 383.33 & 374.66 & 105.8 & 110 & 107.83 \\
\hline \multicolumn{13}{|l|}{ Extracted-hibiscus } \\
\hline $5 \%$ & 371 & 450 & 410.5 & 115 & 136 & 125.5 & 377.66 & 401.66 & 389.66 & 125 & 123.39 & 124.16 \\
\hline $10 \%$ & 380 & 455.66 & 417.83 & 116 & 140.66 & 128.33 & 385 & 396.66 & 390.83 & 125 & 126.66 & 125.83 \\
\hline Means cuts & 354.33 & 437.09 & & 104.63 & 135.04 & & 368.9 & 384.04 & & 114.85 & 117.42 & \\
\hline L.S.D. Treatments & 13.62 & & & 8.27 & & & 13.07 & & & 6.71 & & \\
\hline Cuts & 7.28 & & & 4.425 & & & 6.98 & & & 3.59 & & \\
\hline Interaction Tre.xcuts & 15.93 & & & 9.682 & & & 15.29 & & & 7.85 & & \\
\hline
\end{tabular}


Data showed that, fresh and dry weight (g/plant) was sharp increased with the second cut compared with first cut in two seasons. Looking to the interaction effect between the tested treatments and cuts, it is obvious that all treatments had the lowest fresh and dry herb weights (g/plant.) in $1^{\text {st }}$ Cut in both seasons.

The results obtained showed that foliar application of Geranium plants with ascorbic acid, folic acid as well as hibiscus extract, significantly increase fresh and dry weight the experimental period. These results are in agreement with those obtained by Ghazal (2015) who showed that fresh weight of (Thymus vulgaris L.) herb, significantly responded to ascorbic acid foliar application at different concentrations compared with untreated plant [18]. Similar results were obtained by Balbaa and Talaat (2007) who observed that ascorbic acid treatments significantly increased fresh and dry herb weights of rosemary plants [17]. Foliar treatment of strawberry plants with both concentrations of folic acid, significantly improved agronomic properties of the treated plants including yield, primary and secondary weight of fruits and number of their achenes as compared to the control treatment [26]. The effect of hibiscus extract treatment on fresh and dry weight (g/plant.) may be due to its effect on enzyme activity (cofactors) and metabolism, as it contains; ascorbic acid, mineral elements and anthocyanin.

\subsection{Essential Oil\% and Essential Oil Yield (ml/plant) of Fresh Herb}

Results of the present investigation, presented in (Table 3) and (Figure 2) showed that effect of spray application of ascorbic acid, folic acid and hibiscus extract, on essential oil $\%$ and essential oil yield (ml/plant) of fresh Geranium herb in 2015-2016 and 2016-2017 seasons. Data showed that, oil percentage and oil yield of all treatments significantly increase compared with control in both seasons. Moreover, ascorbic acid at $200 \mathrm{ppm}$, and hibiscus extract at 5\% and $10 \%$ in two seasons were more effective on increasing essential oil\% and essential oil yield (ml/plant) of Geranium.

Regarding the effect of first and second cuts date, results recorded in second cut of the two seasons gave significantly higher essential oil $\%$ and essential oil yield ( $\mathrm{ml} / \mathrm{plant}$ ) than first cut.

Evaluating the interaction effect between treatments and tested cuts, data show that the interactions registered the lowest values of oil percentage and oil yield with first cut in both seasons.

Table 3. Effect of ascorbic acid, folic acid and hibiscus extract on essential oil\% and essential oil yield (ml/plant) from fresh herb of Geranium during 2015/2016-2016/2017 seasons.

\begin{tabular}{|c|c|c|c|c|c|c|c|c|c|c|c|c|}
\hline \multirow{3}{*}{ Treatments } & \multicolumn{6}{|c|}{ First season } & \multicolumn{6}{|c|}{ Second season } \\
\hline & \multicolumn{3}{|c|}{ Essential oil\% } & \multicolumn{3}{|c|}{ Essential oil yield (ml/plant) } & \multicolumn{3}{|c|}{ Essential oil\% } & \multicolumn{3}{|c|}{ Essential oil yield (ml/plant) } \\
\hline & $1^{\text {st }}$ Cut & $2^{\text {nd }}$ Cut & Means & $1^{\text {st }} \mathrm{Cut}$ & $2^{\text {nd }}$ Cut & Means & $1^{\text {st }}$ Cut & $2^{\text {nd }}$ Cut & Means & $1^{\text {st }}$ Cut & $2^{\text {nd }}$ Cut & Means \\
\hline $\begin{array}{l}\text { Control } \\
\text { Ascorbic acid }\end{array}$ & 0.11 & 0.119 & 0.114 & 0.35 & 0.48 & 0.42 & 0.12 & 0.131 & 0.125 & 0.42 & 0.46 & 0.43 \\
\hline $100 \mathrm{ppm}$ & 0.12 & 0.13 & 0.125 & 0.41 & 0.56 & 0.49 & 0.134 & 0.136 & 0.135 & 0.49 & 0.52 & 0.5 \\
\hline $\begin{array}{l}200 \mathrm{ppm} \\
\text { Folic acid }\end{array}$ & 0.131 & 0.149 & 0.14 & 0.46 & 0.65 & 0.55 & 0.143 & 0.146 & 0.145 & 0.53 & 0.56 & 0.54 \\
\hline $\begin{array}{l}100 \mathrm{ppm} \\
\text { Extracted- hibiscus }\end{array}$ & 0.12 & 0.139 & 0.129 & 0.42 & 0.6 & 0.51 & 0.13 & 0.143 & 0.137 & 0.47 & 0.54 & 0.5 \\
\hline $5 \%$ & 0.139 & 0.147 & 0.143 & 0.51 & 0.66 & 0.58 & 0.146 & 0.147 & 0.145 & 0.54 & 0.59 & 0.56 \\
\hline $10 \%$ & 0.143 & 0.151 & 0.147 & 0.53 & 0.68 & 0.61 & 0.155 & 0.158 & 0.156 & 0.59 & 0.62 & 0.6 \\
\hline Means cuts & 0.124 & 0.139 & & 0.439 & 0.608 & & 0.136 & 0.147 & & 0.5 & 0.54 & \\
\hline L.S.D. Treatments & 0.008 & & & 0.035 & & & 0.007 & & & 0.03 & & \\
\hline Cuts & 0.004 & & & 0.019 & & & 0.003 & & & 0.016 & & \\
\hline
\end{tabular}

Essential oil\%

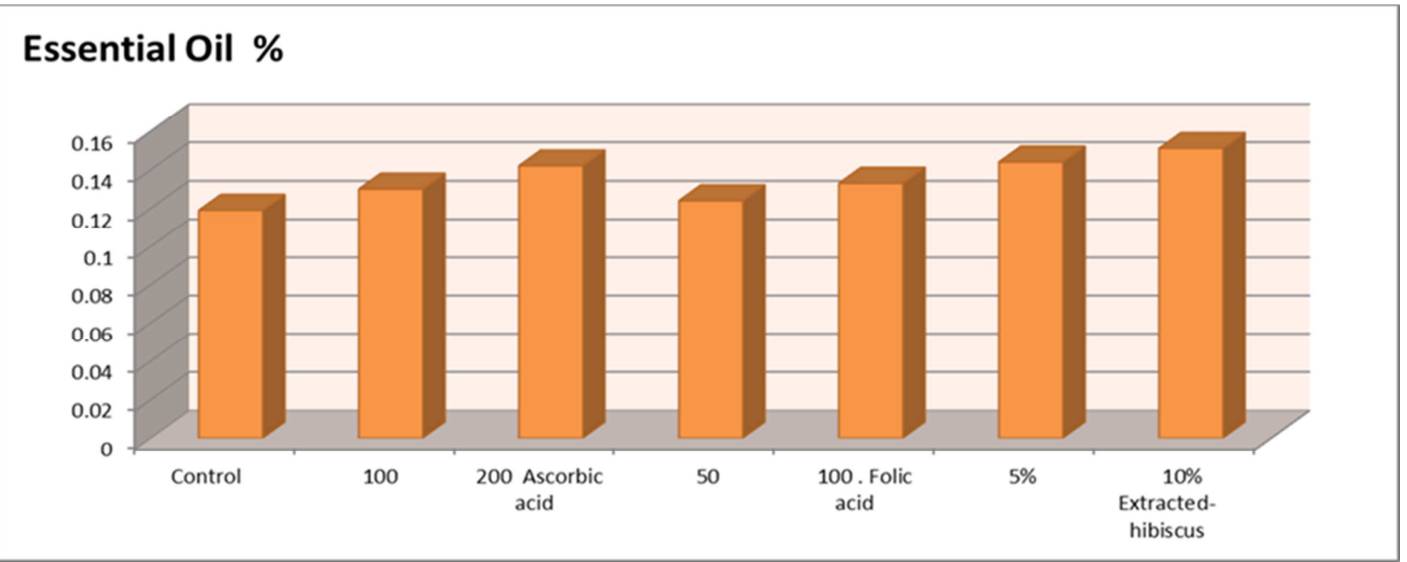

Figure 2. Effect of ascorbic acid, folic acid and hibiscus extract on essential oil\% from fresh herb of Geranium in both seasons. 
These results are consistent with Youssef and Talaat (2003) on rosemary [37], Eid et al., (2010) on Jasminum grandiflorm [38], Taraf et al., (1999) on lemongrass [39] as well as ElLethy et al., (2011) [40] on geranium reported that foliar application of ascorbic acid caused significantly increased in the essential oil\% and oil yield. Ascorbic acid treatment significantly increased oil percentage during the 1st season where ascorbic acid at $150 \mathrm{mg} / 1$ gave the maximum mean values of volatile oil\% in the 1 st and 2 nd cuts on Thymus vulgaris $L$ plant [18]. The effect of hibiscus extract treatment on essential oil \% and essential oil yield (ml/plant) may be due to its positively affected on enzyme activity and metabolism, as it contains; ascorbic acid, mineral elements and anthocyanin.

\subsection{Essential Oil\% and Essential Oil Yield (ml/plant) of Dry Herb}

Table 4 indicated that effect of ascorbic acid, folic acid as well as hibiscus extract on essential oil\% and essential oil yield (ml/plant) from dry herb of Geranium during 2015/2016 - 2016/2017 seasons. Different treatments increased the $\%$ and yield of essential oil (ml/plant) of dry herb in two seasons than treatment control. For essential oil\% and essential oil yield (ml/plant), the higher value from spray ascorbic acid at 100, 200ppm, and hibiscus extract at 5\% and $10 \%$ in first seasons. And also ascorbic acid at 100, 200ppm, folic acid at 100ppm and hibiscus extract at 5\% and $10 \%$ gave increased $\%$ and yield of volatile oil ( $\mathrm{ml} / \mathrm{plant}$ ) of dry herb in second season.

Regarding the effect of first and second cuts date, Data show that, essential oil \% and essential oil yield (ml/plant) of dry herb in first season were significantly increased with the second cut compared with first cut. In Second season not significantly increase between first and second cut. The interaction effect between the treatments and cuts date, it is obvious that all treatments had the lowest essential oil $\%$ and essential oil yield (ml/plant) at first cut in two seasons.

Table 4. Effect of aascorbic acid, folic acid and hibiscus extract on essential oil\% and essential oil yield (ml/plant) from dry herb of Geranium during $2015 / 2016-2016 / 2017$ seasons.

\begin{tabular}{|c|c|c|c|c|c|c|c|c|c|c|c|c|}
\hline \multirow{3}{*}{ Treatments } & \multicolumn{6}{|c|}{ First season } & \multicolumn{6}{|c|}{ Second season } \\
\hline & \multicolumn{3}{|c|}{ Essential oil\% } & \multicolumn{3}{|c|}{ Essential oil yield (ml/plant) } & \multicolumn{3}{|c|}{ Essential oil\% } & \multicolumn{3}{|c|}{ Essential oil yield (ml/plant) } \\
\hline & $1^{\text {st }} \mathrm{Cut}$ & $2^{\text {nd }}$ Cut & Means & $\mathbf{1}^{\text {st }} \mathrm{Cut}$ & $2^{\text {nd }}$ Cut & Means & $1^{\text {st }}$ Cut & $2^{\text {nd }}$ Cut & Means & $\mathbf{1}^{\text {st }} \mathrm{Cut}$ & $2^{\text {nd }}$ Cut & Means \\
\hline Control & 0.291 & 0.303 & 0.297 & 0.27 & 0.371 & 0.32 & 0.298 & 0.31 & 0.304 & 0.309 & 0.314 & 0.312 \\
\hline Ascorbic acid & & & & & & & & & & & & \\
\hline $100 \mathrm{ppm}$ & 0.321 & 0.38 & 0.35 & 0.323 & 0.521 & 0.422 & 0.335 & 0.34 & 0.337 & 0.393 & 0.397 & 0.395 \\
\hline $200 \mathrm{ppm}$ & 0.362 & 0.365 & 0.363 & 0.387 & 0.517 & 0.452 & 0.406 & 0.39 & 0.398 & 0.505 & 0.486 & 0.496 \\
\hline Folic acid & & & & & & & & & & & & \\
\hline $100 \mathrm{ppm}$ & 0.31 & 0.346 & 0.328 & 0.315 & 0.473 & 0.394 & 0.387 & 0.35 & 0.368 & 0.409 & 0.383 & 0.396 \\
\hline Extracted- hibiscus & & & & & & & & & & & & \\
\hline $5 \%$ & 0.353 & 0.366 & 0.36 & 0.405 & 0.497 & 0.451 & 0.425 & 0.42 & 0.422 & 0.531 & 0.516 & 0.524 \\
\hline $10 \%$ & 0.36 & 0.424 & 0.392 & 0.417 & 0.595 & 0.506 & 0.437 & 0.426 & 0.431 & 0.545 & 0.541 & 0.543 \\
\hline Means cuts & 0.328 & 0.362 & & 0.345 & 0.49 & & 0.377 & 0.366 & & 0.436 & 0.428 & \\
\hline L.S.D. Treatments & 0.053 & & & 0.067 & & & 0.053 & & & 0.063 & & \\
\hline Cuts & 0.028 & & & 0.036 & & & 0.028 & & & 0.034 & & \\
\hline
\end{tabular}

\subsection{Fresh and Dry Herbs Yield (ton/fed.)}

Data in (Table 5); generally revealed that when spray application of ascorbic acid, folic acid and hibiscus extract, on fresh and dry herbs yield (ton/fed.) of Geranium in 20152016 and 2016-2017 seasons. Data showed that all treatments increased fresh and dry herbs yield (ton/fed.) than control. And also in the first season ascorbic acid at 200ppm, folic acid $100 \mathrm{ppm}$ and hibiscus extract 5, 10\% achieved significantly the highest yield [fresh and dry (ton/fed.)] expressed as weight. Besides, the highest yield in second season with ascorbic acid at 100, 200ppm, folic acid $100 \mathrm{ppm}$ and hibiscus extract 5, 10\%.

Regarding the effect of first and second cuts date, results recorded in second cut of the first season gave significantly higher fresh and dry herbs yield (ton/fed.) than first cut. On the other side, in the $2^{\text {nd }}$ season no significant differences were observed between first and second cut.

The interaction effect between the treatments $\mathrm{x}$ cuts date, it is obvious that all treatments had the lowest fresh and dry yields (ton /fed.) at $1^{\text {st }}$ Cut in two seasons.

Table 5. Effect of ascorbic acid, folic acid and hibiscus extract on fresh and dry herbs yield (ton/fed.) of Geranium during 2015/2016 - $2016 / 2017$ seasons.

\begin{tabular}{|c|c|c|c|c|c|c|c|c|c|c|c|c|}
\hline \multirow{3}{*}{ Treatments } & \multicolumn{6}{|c|}{ First season } & \multicolumn{6}{|c|}{ Second season } \\
\hline & \multicolumn{3}{|c|}{ Fresh yield (Ton/Fed.) } & \multicolumn{3}{|c|}{ Dry yield (Ton/Fed.) } & \multicolumn{3}{|c|}{ Fresh yield (Ton/Fed.) } & \multicolumn{3}{|c|}{ Dry yield (Ton/Fed.) } \\
\hline & $1^{\text {st }}$ Cut & $2^{\text {nd }}$ Cut & Means & $1^{\text {st }} \mathrm{Cut}$ & $2^{\text {nd }} \mathrm{Cut}$ & Means & $1^{\text {st }} \mathrm{Cut}$ & $2^{\text {nd }}$ Cut & Means & $1^{\text {st }} \mathrm{Cut}$ & $2^{\text {nd }} \mathrm{Cut}$ & Means \\
\hline Control & 9.8 & 12.4 & 11.16 & 2.8 & 3.6 & 3.2 & 11.1 & 10.8 & 10.96 & 3.1 & 3 & 3.05 \\
\hline Ascorbic acid & & & & & & & & & & & & \\
\hline $100 \mathrm{ppm}$ & 10.4 & 12.9 & 11.7 & 3.1 & 4.12 & 3.55 & 11 & 11.5 & 11.28 & 3.5 & 3.5 & 3.48 \\
\hline $200 \mathrm{ppm}$ & 10.7 & 13.2 & 11.95 & 3.2 & 4.2 & 3.7 & 11.13 & 11.6 & 11.35 & 3.7 & 3.7 & 3.73 \\
\hline Folic acid & & & & & & & & & & & & \\
\hline
\end{tabular}




\begin{tabular}{|c|c|c|c|c|c|c|c|c|c|c|c|c|}
\hline \multirow{3}{*}{ Treatments } & \multicolumn{6}{|c|}{ First season } & \multicolumn{6}{|c|}{ Second season } \\
\hline & \multicolumn{3}{|c|}{ Fresh yield (Ton/Fed.) } & \multicolumn{3}{|c|}{ Dry yield (Ton/Fed.) } & \multicolumn{3}{|c|}{ Fresh yield (Ton/Fed.) } & \multicolumn{3}{|c|}{ Dry yield (Ton/Fed.) } \\
\hline & $\mathbf{1}^{\text {st }} \mathrm{Cut}$ & $2^{\text {nd }}$ Cut & Means & $1^{\text {st }} \mathrm{Cut}$ & $2^{\text {nd }} \mathrm{Cut}$ & Means & $1^{\text {st }} \mathrm{Cut}$ & $2^{\text {nd }}$ Cut & Means & $1^{\text {st }}$ Cut & $2^{\text {nd }}$ Cut & Means \\
\hline $50 \mathrm{ppm}$ & 10.2 & 12.9 & 11.56 & 2.9 & 3.9 & 3.4 & 10.76 & 11.3 & 11.03 & 3 & 3.3 & 3.18 \\
\hline $100 \mathrm{ppm}$ & 10.6 & 13 & 11.85 & 3 & 4 & 3.53 & 10.9 & 11.5 & 11.23 & 3.1 & 3.3 & 3.2 \\
\hline \multicolumn{13}{|l|}{ Extracted- hibiscus } \\
\hline $5 \%$ & 11.1 & 13.5 & 12.3 & 3.4 & 4 & 3.73 & 11.3 & 12 & 11.66 & 3.7 & 3.7 & 3.71 \\
\hline $10 \%$ & 11.4 & 13.6 & 12.53 & 3.4 & 4.2 & 3.81 & 11.5 & 11.9 & 11.71 & 3.7 & 3.8 & 3.76 \\
\hline Means cuts & 10.63 & 13.09 & & 3.11 & 4 & & 11.12 & 11.51 & & 3.41 & 3.48 & \\
\hline L.S.D. Treatments & 0.43 & & & 0.269 & & & 0.496 & & & 0.207 & & \\
\hline Cuts & 0.23 & & & 0.143 & & & 0.265 & & & 0.11 & & \\
\hline Interaction Tre.xcuts & 0.5 & & & 0.313 & & & 0.578 & & & 0.242 & & \\
\hline
\end{tabular}

The results obtained showed that foliar application of Geranium plants with ascorbic acid, folic acid, hibiscus extract; a great increase fresh and dry weight (ton/fed.) the experimental period. These results are in agreement with those obtained by Ghazal (2015) showed that fresh weight herb, significantly responded to ascorbic acid at different concentrations compared with untreated plants (Thymus vulgaris L.) [18]. Similar results were obtained by Balbaa and Talaat (2007) who showed that ascorbic acid treatment significantly fresh and dry herb weights of rosemary plants [17]. Foliar treatment of strawberry plants with both concentrations of folic acid significantly improved agronomic properties of the treated plants including yield, primary and secondary weight of fruits and number of their achene's as compared to the control treatment and also found that folic acid enhances fruit quality and yield of strawberry [26]. The effect of hibiscus extract treatment on fresh and dry weight (g/plant.) may be due to its positively affected on enzyme activity and metabolism, as it contains; ascorbic acid, mineral elements and anthocyanin.

\subsection{Essential Oil Yield (L/fed.) from Fresh and Dry Herbs}

Table 6 indicated that effect of ascorbic acid, folic acid as well as hibiscus extract on essential oil yield (L/fed.) from fresh and dry herbs of Geranium during 2015/20162016/2017 seasons. Different treatments increased the essential oil yield (L/fed.) in first and second seasons than control treatment. For essential oil yield (L/fed.) from fresh herb, the higher value from spray ascorbic acid at $200 \mathrm{ppm}$ and hibiscus extract at 5\% and $10 \%$ in two seasons. And also ascorbic acid at 200ppm, folic acid at $100 \mathrm{ppm}$ and hibiscus extract at $5 \%$ and $10 \%$ gave increased essential oil yield (L/fed.) from dry herb in in both seasons.

Table 6. Effect of ascorbic acid, folic acid and hibiscus extract on essential oil yield (L/fed.) from fresh and dry herbs of Geranium during 2015/2016 2016/2017 seasons.

\begin{tabular}{|c|c|c|c|c|c|c|c|c|c|c|c|c|}
\hline \multirow{3}{*}{ Treatments } & \multicolumn{6}{|c|}{ First season } & \multicolumn{6}{|c|}{ Second season } \\
\hline & \multicolumn{3}{|c|}{$\begin{array}{l}\text { Essential oil yield (L/fed.) } \\
\text { from fresh herb }\end{array}$} & \multicolumn{3}{|c|}{$\begin{array}{l}\text { Essential oil yield (L/fed.) } \\
\text { from dry herb }\end{array}$} & \multicolumn{3}{|c|}{$\begin{array}{l}\text { Essential oil yield (L/fed.) } \\
\text { from fresh herb }\end{array}$} & \multicolumn{3}{|c|}{$\begin{array}{l}\text { Essential oil yield (L/fed.) } \\
\text { from dry herb }\end{array}$} \\
\hline & 1 $^{\text {st }} \mathrm{Cut}$ & $2^{\text {nd }}$ Cut & Means & $1^{\text {st }} \mathrm{Cut}$ & $2^{\text {nd }} \mathrm{Cut}$ & Means & $1^{\text {st }} \mathrm{Cut}$ & $2^{\text {nd }} \mathrm{Cut}$ & Means & $1^{\text {st }} \mathrm{Cut}$ & $2^{\text {nd }} \mathrm{Cut}$ & Means \\
\hline Control & 10.7 & 14.6 & 12.65 & 8.07 & 11.13 & 9.6 & 12.5 & 13.8 & 13.16 & 9.28 & 10.24 & 9.76 \\
\hline \multicolumn{13}{|l|}{ Ascorbic acid } \\
\hline $100 \mathrm{ppm}$ & 12.5 & 17 & 14.75 & 9.61 & 15.64 & 12.62 & 14.8 & 15.5 & 15.15 & 11.79 & 11.91 & 11.85 \\
\hline $200 \mathrm{ppm}$ & 13.9 & 19.6 & 16.75 & 11.61 & 15.52 & 13.56 & 15.9 & 16.9 & 16.4 & 15.17 & 14.6 & 14.88 \\
\hline \multicolumn{13}{|l|}{ Folic acid } \\
\hline $50 \mathrm{ppm}$ & 10.9 & 17.3 & 14.1 & 8.95 & 13.85 & 11.4 & 13.7 & 14.8 & 14.25 & 10.93 & 10.81 & 10.87 \\
\hline $100 \mathrm{ppm}$ & 12.7 & 17.8 & 15.25 & 9.46 & 14.19 & 11.82 & 13.3 & 16.3 & 14.8 & 12.28 & 11.51 & 11.89 \\
\hline \multicolumn{13}{|l|}{ Extracted-hibiscus } \\
\hline $5 \%$ & 15.5 & 19.8 & 17.65 & 12.16 & 14.92 & 13.54 & 16.3 & 17.6 & 16.95 & 15.94 & 15.5 & 15.72 \\
\hline $10 \%$ & 16.1 & 20.5 & 18.35 & 12.51 & 17.85 & 15.18 & 17.8 & 18.7 & 18.26 & 16.36 & 16.25 & 16.3 \\
\hline Means cuts & 13.18 & 18.1 & & 10.33 & 14.72 & & 14.9 & 16.22 & & 13.1 & 12.97 & \\
\hline L.S.D. Treatments & 1.09 & & & 2.029 & & & 0.723 & & & 1.97 & & \\
\hline Cuts & 0.582 & & & 1.08 & & & 0.386 & & & 1.054 & & \\
\hline Interaction Tre.xcuts & 1.272 & & & 2.371 & & & 0.845 & & & 2.305 & & \\
\hline
\end{tabular}

Regarding the effect of first and second cuts date, results recorded in second cut of the first season gave significantly higher essential oil yield (L/fed.) from fresh and dry herbs than first cut. On the other hand in the second season no significant differences were observed between first and second cut of essential oil yield (L/fed.) from dry herb. But essential oil yield (L/fed.) from fresh herb showed that significant differences between first and second cut in two seasons.

Evaluating the interaction effect between treatments $\mathrm{x}$ tested cuts, data show that the interactions registered the lowest values of essential oil yield (L/fed.) from fresh and dry herbs with $1^{\text {st }}$ Cut in both seasons. The results obtained showed that foliar application of Geranium plants with ascorbic acid, folic acid, hibiscus extract; a great increase volatile oil yield (L/fed.) from fresh and dry herbs. These results are in agreement with those obtained by Taraf et al., (1999) on lemongrass [39], Youssef and Talaat (2003) on rosemary [37], Eid et al., (2010) on Jasminum grandiflorm [38] as well as El-Lethy et al., (2011) [40] on geranium 
reported that foliar application of ascorbic acid caused pronounced increased in the yield of essential oil. Ascorbic acid treatment significantly increased oil percentage during the 1 st season where ascorbic acid at $150 \mathrm{mg} / 1$ gave the maximum mean values of volatile oil $\%$ in the 1 st and 2 nd cuts on Thyme plant [18]. Pronounced increases in the growth characters of Ammi visnaga L. plants were obtained as a result of ascorbic acid treatments [41]. This synergistic effect of ascorbic acid might be due to its involvement in the main metabolic processes, especially with energy coenzymes [42]. Foliar of strawberry plants with both concentrations of folic acid, significantly improved agronomic characteristics of the treated plants including yield, primary and secondary weight of fruits and number of their achenes as compared to the control treatment [26]. The effect of hibiscus extract treatment on yield of essential oil may be due to its positively affected on enzyme activity and metabolism, as it contains; ascorbic acid, mineral elements and anthocyanin.

\subsection{Effect of Ascorbic Acid, Folic Acid, Hibiscus Extract and Natural Drying (NA) on Oil Yield Production (L/fed.)}

From data in (Table 7) and (Figure 3) show that NA (natural drying) increased oil loss from dry herb (L/fed.) compared to fresh herb during 2015/2016-2016/2017 seasons. On the other hand the oil loss by NA 5.00- 6.00 (L/fed.) and weight loss of herb to $70 \%$ from fresh herb Table 5 reducing transport and distillation costs percentage $70 \%$. The Geranium product should compare oil lost (5-6) L/fed. to reducing costs (distillation and transportation). The herb may be left to wilt in the field for 72 hours (3 days) to allow for better vaporization of moisture and greater packing of biomass in the distillation vessel [43]. Extending the drying time over 3-4 days caused reduction in oil yield, which may be attributed to volatile oil loses caused by wind, temperature and plant part loses [44].

Table 7. Effect of ascorbic acid, folic acid, hibiscus extract and natural drying on oil yield Production (L/fed.) from fresh and dry herbs of Geranium during 2015/2016-2016/2017 seasons.

\begin{tabular}{|c|c|c|c|c|c|c|}
\hline \multirow[b]{2}{*}{ Treatments } & \multicolumn{3}{|l|}{ First season } & \multicolumn{3}{|l|}{ Second season } \\
\hline & $\begin{array}{l}\text { Oil yield from } \\
\text { fresh herb (L/fed.) }\end{array}$ & $\begin{array}{l}\text { Oil yield from dry } \\
\text { herb (L/fed.) }\end{array}$ & $\begin{array}{l}\text { Oil loss from NA } \\
\text { (L/fed.) }\end{array}$ & $\begin{array}{l}\text { Oil yield from } \\
\text { fresh herb (L/fed.) }\end{array}$ & $\begin{array}{l}\text { Oil yield from dry } \\
\text { herb (L/fed.) }\end{array}$ & $\begin{array}{l}\text { Oil loss from NA } \\
\text { (L/fed.) }\end{array}$ \\
\hline Control & 25.3 & 19.2 & 6.1 & 26.3 & 19.52 & 6.7 \\
\hline \multicolumn{7}{|l|}{ Ascorbic acid } \\
\hline $100 \mathrm{ppm}$ & 29.5 & 25.2 & 4.3 & 30.3 & 23.7 & 6.6 \\
\hline $200 \mathrm{ppm}$ & 33.5 & 27.1 & 6.4 & 32.8 & 29.7 & 3 \\
\hline \multicolumn{7}{|l|}{ Folic acid } \\
\hline $100 \mathrm{ppm}$ & 30.4 & 23.6 & 6.8 & 29.6 & 23.7 & 5.9 \\
\hline \multicolumn{7}{|c|}{ Extracted- hibiscus } \\
\hline $5 \%$ & 35.3 & 27 & 8.3 & 33.9 & 31.4 & 2.5 \\
\hline $10 \%$ & 36.6 & 30.3 & 6.3 & 36.5 & 32.6 & 3.9 \\
\hline Means & 31.2 & 25 & 6.22 & 31.11 & 26.04 & 5 \\
\hline
\end{tabular}

Oil yield (L/fed.)

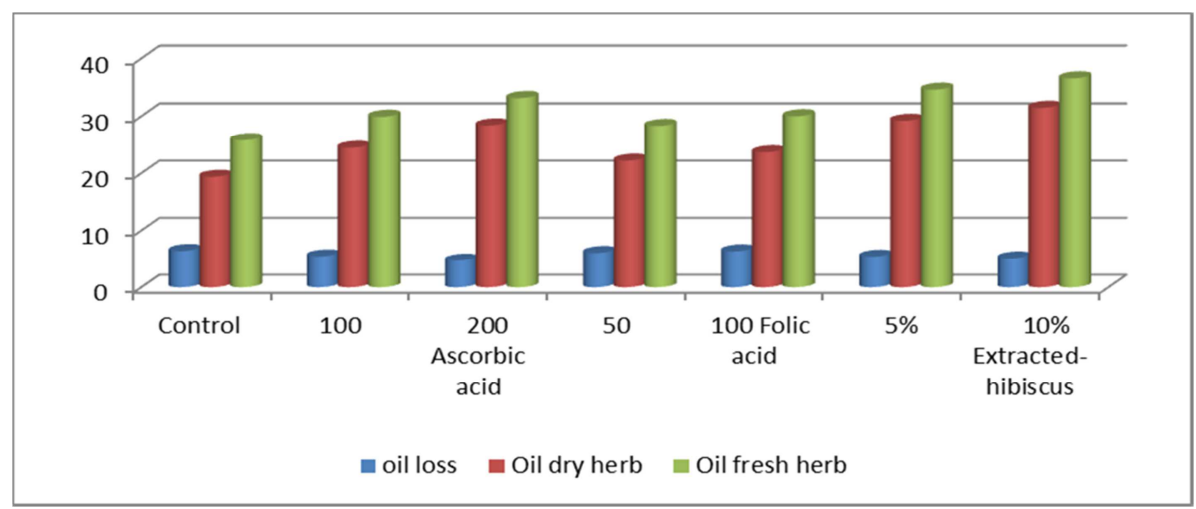

Figure 3. Effect of ascorbic acid, folic acid, hibiscus extract and natural drying on oil yield (L/fed.) from fresh and dry herbs of Geranium in both seasons.

\subsection{Effect of Natural Drying on Active Compounds}

Data were presented in (Table 8) and (Figure 4): effect of NA (natural drying) on active compounds of Geranium during 2016/2017 season. The percentages of components showed that, the Citronellol represented the main compound, followed by Geraniol, Eugenol, Geranyl formate, Citronelly formate, Iso-menthone, B-caryophyllene, Linalool and, $\alpha$ - pinene ordered from high to low. Moreover observed that natural drying caused pronounced increasing in the main constituents (Citronellol, Eugenol, Geranyl formate, Citronelly formate and Iso-menthone) on the other beside caused pronounced decreasing of Geraniol, B-caryophyllene, Linalool and, $\alpha$-pinene.

Drying herbal yield of geranium up to 3 to 4 days does not affect the physicochemeical traits of the volatile oil, rather 
increases slightly the yield and quality, reduces the staking volume and thus the transportation and distillation costs; consequently encourage geranium plantations to extend in new areas far from distillation factories [44].

Table 8. Effect of natural drying $\left(20 \pm 2^{\circ} \mathrm{C}\right)$ on active compounds of Geranium essential oil during $2^{\text {nd }}$ Cut, $2016 / 2017$ season.

\begin{tabular}{llll}
\hline Active compounds (\%) & Oil-fresh herb & Oil-dry herb \\
\hline 1 & $\alpha$-pinene & 0.53 & 0.6 \\
2 & Iso-menthone & 4.55 & 5.29 \\
3 & Linalool & 3.88 & 2.74 \\
4 & Citronelly formate & 5.62 & 6.63 \\
5 & Geranyl formate & 5.65 & 5.45 \\
6 & Citronerlol & 33.81 & 37.43 \\
7 & Geraniol & 26.52 & 22.86 \\
8 & Eugenol & 8.3 & 8.74 \\
9 & B-caryophyllene & 4.32 & 3.3 \\
10 & Total identified compounds & $93.18 \%$ & $93.04 \%$ \\
11 & Other compounds & $6.82 \%$ & $6.96 \%$ \\
12 & total compounds & $100 \%$ & $100 \%$ \\
\hline
\end{tabular}

Active compounds\%

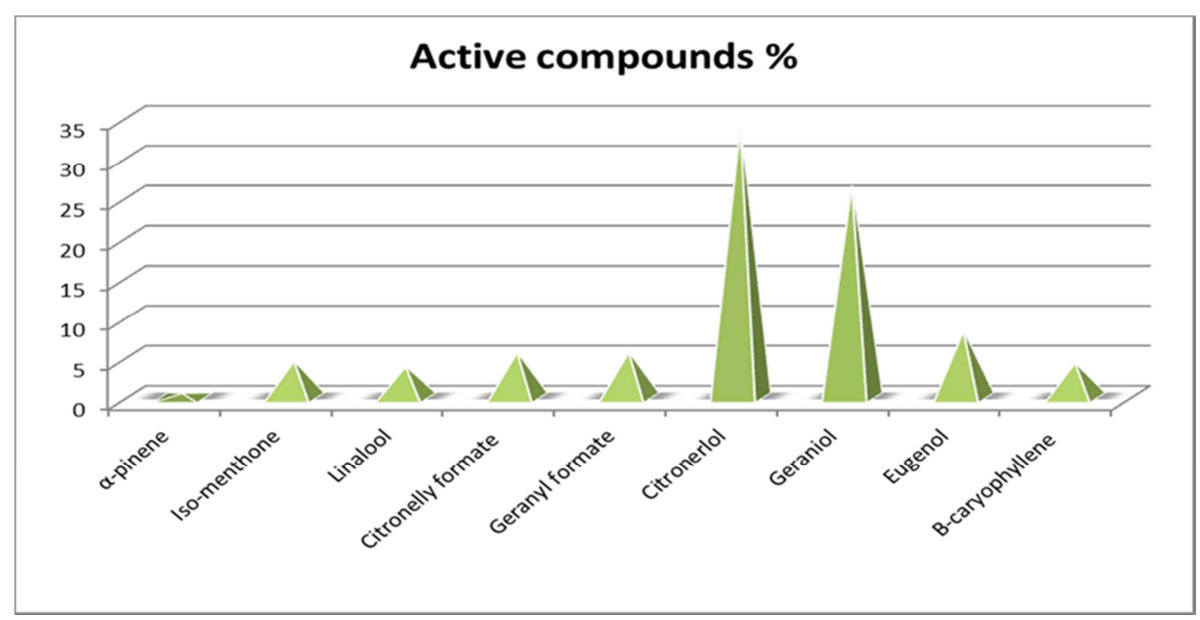

Figure 4. Active compounds of Geranium essential oil from fresh herb.

\subsection{Effect of Ascorbic Acid, Folic Acid and Hibiscus Extract on Active Compounds}

Data concerning the effect of ascorbic acid, folic acid and hibiscus extract on active compounds of Geranium essential oil during $2^{\text {nd }}$ Cut, 2016/2017 season are reported in (Table 9). Results showed that active compounds were 9 compounds representing about $88.11 \%-97.09 \%$ as a result of different treatments during 2016-2017 season. Citronerlol was identified as the major compound in the different treatments ranging from $31.55 \%$ to $40.99 \%$. Geraniol the second main component, ranged $19.29 \%-27.11 \%$ in the essential oil followed with Eugenol which was identified as the third compounds in the volatile oil and its relative percentage accounted for $8.30 \%-10.18 \%$. And results indicated that all treatments caused increase main constituents; Citronerlol, Citronelly formate, Iso-menthone, B-caryophyllene and Geranyl formate. On the other beside all treatments caused a reduction in Geraniol and $\alpha$-pinene. The effect of ascorbic acid on volatile oil constituents may be due to its effect on enzyme activity and metabolism of essential oil production [18]. Folic acid (vitamin B9) has become the most prominent of Bcomplex vitamins despite its essential biochemical function in amino acids metabolism and nucleic acids synthesis [23]. The effect of hibiscus extract treatment on essential oil and its constituents may be due to its positively affected on enzyme activity and metabolism of essential oil production, as it contains; Ascorbic acid, mineral elements and anthocyanin.

Table 9. Effect of ascorbic acid, folic acid and hibiscus extract on active compounds of Geranium essential oil during $2^{\text {nd }}$ Cut, 2016/2017 season

\begin{tabular}{|c|c|c|c|c|c|c|c|c|}
\hline \multirow{2}{*}{ Compounds\% } & \multirow{2}{*}{ Treatments } & \multirow{2}{*}{ Control } & \multicolumn{2}{|c|}{ Ascorbic acid } & \multicolumn{2}{|c|}{ Folic acid } & \multicolumn{2}{|c|}{ Extracted- hibiscus } \\
\hline & & & 100 ppm & 200 ppm & 50 ppm & 100 ppm & $5 \%$ & $10 \%$ \\
\hline$\alpha$-pinene & & 2.37 & 0.33 & 0.35 & 0.24 & 0.45 & 0.53 & 0.29 \\
\hline Iso-menthone & & 4.61 & 4.88 & 4.99 & 6.99 & 4.63 & 4.55 & 4.74 \\
\hline linalool & & 2.45 & 1.64 & 4.99 & 1.65 & 2.95 & 3.88 & 2.54 \\
\hline Citronelly formate & & 4.75 & 5.95 & 6.66 & 7.17 & 7.85 & 5.62 & 4.74 \\
\hline Geranyl formate & & 2.09 & 3.97 & 6.42 & 6.44 & 4.97 & 5.65 & 5.04 \\
\hline Citronerlol & & 31.55 & 40.99 & 33.7 & 36.57 & 36.08 & 33.81 & 35.97 \\
\hline
\end{tabular}




\begin{tabular}{|c|c|c|c|c|c|c|c|}
\hline \multirow{2}{*}{$\begin{array}{ll}\text { Compounds\% } & \text { Treatments } \\
\end{array}$} & \multirow{2}{*}{ Control } & \multicolumn{2}{|c|}{ Ascorbic acid } & \multicolumn{2}{|c|}{ Folic acid } & \multicolumn{2}{|c|}{ Extracted- hibiscus } \\
\hline & & 100 ppm & 200 ppm & 50 ppm & 100 ppm & $5 \%$ & $10 \%$ \\
\hline Geraniol & 28.3 & 20.16 & 25.81 & 23.2 & 19.29 & 26.52 & 27.11 \\
\hline Eugenol & 9.49 & 10.17 & 8.27 & 10.18 & 9.26 & 8.3 & 8.54 \\
\hline B-caryophyllene & 2.5 & 5.49 & 2.1 & 4.65 & 4.65 & 4.32 & 5.36 \\
\hline Total identified compounds & 88.11 & 93.58 & 93.29 & $97.09 \%$ & 90.13 & $93.18 \%$ & 94.33 \\
\hline Other compounds & 11.89 & 6.42 & 6.71 & $2.91 \%$ & 9.87 & $6.82 \%$ & 5.67 \\
\hline total compounds & $100 \%$ & $100 \%$ & $100 \%$ & $100 \%$ & $100 \%$ & $100 \%$ & $100 \%$ \\
\hline
\end{tabular}

\section{Conclusion}

In the present study, it could be concluded that using ascorbic acid at $200 \mathrm{ppm}$, folic acid at $100 \mathrm{ppm}$ and extracthibiscus 5 and $10 \%$ were better treatments in increasing vegetative growth, higher volatile oil content and active compounds than other treatments. Effect of natural drying; it increased oil loss from dry herb (L/fed.) Compared to fresh herb. On the other hand the oil loss by natural drying/ fed. 5.00- $6.00(\mathrm{~L} /$ fed.) and weight loss of herb to $70 \%$ from fresh herb reducing transport and distillation costs by $70 \%$. The Geranium product should compare the lost oil (5-6, L/fed.) to reducing costs (distillation and transportation).

\section{References}

[1] Bulletin of the Agricultural Statistics. part (1): 2017, part (2) 2018.

[2] Misra A, Srivastava NK. Value addition of essential monoterpene oil (s) in Geranium (Pelargonium graveolens) on leaf positions for commercial exploitation. African J. of Agr. Res. 5 (15), 2010, 2077-2079.

[3] Rao BRR, Kaul PN, Syamasundar KV, Ramesh S. Water soluble fractions of rose-scented geranium (Pelargonium species) essential oil. Bioresource Technology. 84 (3), 2002, 243-246.

[4] Rao BRR. Biomass yield, essential oil yield and essential oil composition of rose-scented geranium (Pelargonium species) as influenced by row spacings and intercropping with cornmint (Mentha arvensis L. f. piperascens Malinv. ex Holmes). Industrial Crops and Products. 16 (2), 2002, 133144.

[5] Lis-Balchin M, Patel J, Hart S. Studies on the mode of action of essential oils of scented-leaf Pelargonium (Geraniaceae). Phytotherapy Research. 12 (3) 1998, 215- 217.

[6] Peterson A, Machmudah S, Roy BC, Goto M, Sasaki M, Hirose T. Extraction of essential oil from geranium (Pelargonium graveolens) with supercritical carbon dioxide. Journal of Chemical Technology and Biotechnology. 81 (2) 2006, 167-172.

[7] Fayed SA. Antioxidant and anticancer activities of Citrus reticulate (petitgrain mandarin) and Pelargonium graveolens (geranium) essential oils. Res. J. Agr. and Biol. Sci. 5 (5), 2009, 740-747.

[8] Weiss EA. Essential Oil Crops. Centre for Agriculture and Biosciences (CAB) International, New York, 1997.

[9] Miller DM. The taxonomy of Pelargonium species and cultivars, their origins and growth in the wild. Geranium and
Pelargoniums: The genera Geranium and Pelargonium. In: Medicinal and Aromatic PlantsIndustrial Profiles. Lis-Balchin M (Ed.). Taylor and Francis, London, 2002, 49-79.

[10] Higley C, Higley A. Reference Guide for Essential Oils. Abundant Health, London, 2001.

[11] Abd El-Gawad, M. G., El-Moghazy T. F. A. Extracting some Essential Oils and Studying their Effects on Extending Storage Life and Improving Quality of "Florida Prince" Peach Fruits. Middle East J. Agric. Res., 7 (4), 2018, 1545-1560, ISSN: 2077-4605.

[12] Khan MG, Srivastava HS. Changes in growth and nitrogen assimilation in maize plants induced by $\mathrm{NaCl}$ and growth regulators. Biol. Plant., 41, 1998, 93-99.

[13] Al-Hakimi AMA, Hamada AM. Counteraction of salinity stress on wheat plants by grain soaking in ascorbic acid, thiamin or sodium salicylate. Biol. Plant., 44, 2001, 253-261.

[14] El-Tohamy W. A, El-Abugy H. M, El-Gready N. H. M. Studies on the effect putrescine, yeast and vitamin $\mathrm{C}$ on growth, yield and physiological responses of eggplant (Solanum melongena L.) under sandy soil conditions. Aust. J. Basic Appl. Sci., 2 (2), 2008, 296-300.

[15] El-Tohamy WA, El-Gready NHM. Physiological responses, growth, yield and quality of snap beans in response to foliar application of yeast, vitamin $\mathrm{E}$ and zinc under sandy soil conditions. Aust. J. Basic Appl. Sci., 1 (3), 2007, 294-299.

[16] Shehata SM, Helmy YI, El-Tohamy WA. Pepper plants as affected by foliar application with some chemical treatments under later summer conditions. Egypt J. Appl. Sci., 17 (7), 2002, 236-248.

[17] Balbaa L. K., Talaat I. M. Physiological response of rosemary plants (Rosmarinus officinalis L.) to ascorbic acid, phenylalanine and ornithine. Egypt. J. Appl. Sci. 22 (11B) 2007, 375-385.

[18] Ghazal G. M. Growth and oil yield of thymus vulgaris plant as influenced by some amino acids and ascorbic acid, World J Pharm Sci, 3 (10) 2015, 1957-1966.

[19] Asada, K. The water-water cycle in chloroplasts, scavenging of active oxygens and dissipation of excess photons. Annu Rev of Plant Physiol and Plant Mol. Biol. 50, 1999, 601-639.

[20] Conklin, P. Recent advances in the role and biosynthesis of ascorbic acid in plants. Plant, Cell and Environ. 24: 2001, 383-394.

[21] Pignocchi, C. and C. Foyer. Apoplastic ascorbate metabolism and its role in the regulation of cell signaling. Curr. Opin. Plant Biol. 6, 2003, 379-389.

[22] El-Kobisy, D. S.; Kady K. A.; Hedani, R. A. and Agamy, R. A. Response of pea plant (pisum sativum $L$.) to treatment with ascorbic acid. Egypt. J. Appl. Sci., 20, 2005, 36-50. 
[23] Andrew WJ, Youngkoo C, Chen X, Pandalai SG. Vicissitudes of a vitamin. Recent Res. Dev. Phytochem., 4, 2000, 89-98.

[24] Cossins E. The fascinating word of folate and one-crbon metabolism. J. of Bot. 78, 2000, 691-708.

[25] Wang Z, Li S and Malhi S. Effects of fertilization and other agronomic measures on nutritional quality of crops. Review. J. of the Sci. of Food and Agr. 88, 2008, 7-23.

[26] Raeisi, J., Pakkish, Z., Saffari, V. R. Efficiency of Folic Acid in Improving Yield and Fruit Quality of Strawberry. J. of Plant Physiology \& Breeding, 7 (1), 2017, 15-25.

[27] Nman, N. M., Onyeke, N. G. Chemical composition of two varieties of Sorrel (Hibiscus sabdarifa L.), calyces and the drink made from them. Plant Foods for Human Nutrition, 2003, 58, 1-7.

[28] Ali, B. H., Al Wabel, N., Blunden, G. Phytochemical, pharmacological and toxicological aspects of Hibiscus sabdariffa L. Phytotherapy Research, 19, 2005, 369-375.

[29] Haji-Faraji, M., Haji-Tarkhani, A. The effect of sour tea (Hibiscus sabdariffa) on essential hypertension. Journal of Ethnopharmacology, 65, 1999, 231-236.

[30] Herrera-Arellano, A., Flores-Romero, S., Chavez-Soto, M. A., Tortoriello, J. Effectiveness and tolerability of a standardized extract from Hibiscus sabdariffa in patients with mild to moderate hypertension: a control and randomized clinical trial. Phytomedicine, 11, 2004, 375-382.

[31] Eltayeib A. A., Hamade H. Phytochemical and Chemical Composition of Water Extract of Hibiscus Sabdariffa (Red Karkade Calyces) in North Kordofan State-Sudan Int, J. of Adv. Res. in Chem. Sci. (IJARCS) Vol. 1, Is. 6, Aug., 2014, PP 10-13 ISSN 2349-039X (Print), ISSN 2349-0403 (Online) www.arcjournals.org

[32] Alshoash W. G. A. Chetnical Composition of Some Roselle (Hibiscus sabdariffa Genotypes., (M.SC.) Fac. of Agr., Uni. of Khartoum 1997.

[33] Gingasu, D., Mindru, I., Patron, L., Calderon-Moreno, J. M., Mocioiu, O. C., Preda, S., Stanica, N., Nita, S., Dobre, N., Popa, M. and Gradisteanu, G. Green synthesis methods of $\mathrm{CoFe}_{2} \mathrm{O}_{4}$ and $\mathrm{Ag}-\mathrm{CoFe}_{2} \mathrm{O}_{4}$ nanoparticles using hibiscus extracts and their antimicrobial potential. Journal of Nanomaterials, Vol. 2016, Article ID 2106756, 12 pages http://dx.doi.org/10.1155/2016/2106756
[34] British Pharmacopoeia The pharmaceutical press 17 Bloomsburg, square. W. C. I. London. 1963.

[35] Gomez, K. A., A. A. Gomez, Statistical procedure for agricultural research. 2nd Edition. 1984, pp. 8-22.

[36] Emam, M. M., El-Sweify, A. H., \& Helal, N. M. Efficiencies of some vitamins in improving yield and quality of flax plant. African Journal of Agricultural Research, 6 (18), 2011, 43624369.

[37] Youssef, AA. and Talaat I M,. Physiological response of rosemary plants to some vitamins. Egypt. Pharm. J., 1: 2003, 81-93.

[38] Eid, R. A., S. T. Lobna, M. M. Soad. "Physiological properties studies on essential oil of Jasminum grandiflorum L. as affected by some vitamins." Ozean J. of Appl. Sci. 3, no. 1, 2010, 87-96.

[39] Taraf, S. A., Gamal El-Din, K. M., Balbaa, L. K. The response of vegetative growth and essential oil of lemongrass (Cymbopogon citrates Hort) to foliar application of ascorbic acid, nicotinamid and some micronutrients. Arab Univ. of Agric. Sci., 7, 1999, 247-259.

[40] El-Lethy, S. R., Ayad, H. S. and Reda, F. Effect of riboflavin, ascorbic acid and dry yeast on vegetative growth, essential oil pattern and antioxidant activity of geranium (Pelargonium graveolens L.). American-Eurasian J. of Agr, and Environmental Sci., 10, 2011, pp. 781-786.

[41] Reda, F.; Fadl, M.; Abdel-All, R. S. and El-Moursi, A. Physiological studies on Ammi visnaga L. The effect of thiamine and ascorbic acid on growth and chromone yield. Egypt. J. Pharm. Sci., 18, 1977, 19-27. Aberg, B. (1961): Vitamins as growth factors in higher plants. Encyclopedia of Plant Physiol. XIV. 418-449.

[42] Aberg, B. Vitamins as growth factors in higher plants. Encyclopedia of Plant Physiol. XIV. 1961, 418-449.

[43] ADC Commercialization Bulletin No. 14 Geranium oil. IDEA/ Geranium oil /March 12, 1998.

[44] Hamouda A. M. A. Effect of Drying Geranium Fresh Herb Before Distillation on Essential Oil Yield and Composition, Egypt. J. Hort. Vol. 40, No. 1, 2013, pp. 113-120. 